Center for the Advancement of Sustainability Innovations (CASI)

\title{
Emerging Challenges and Opportunities in Building Information Modeling for the US Army Installation Management Command
}

Beth A. Brucker, E. William East, Lance R. Marrano, July 2012

Michael P. Case, William D. Goran, Allan Carroll, and Gus DeJesus

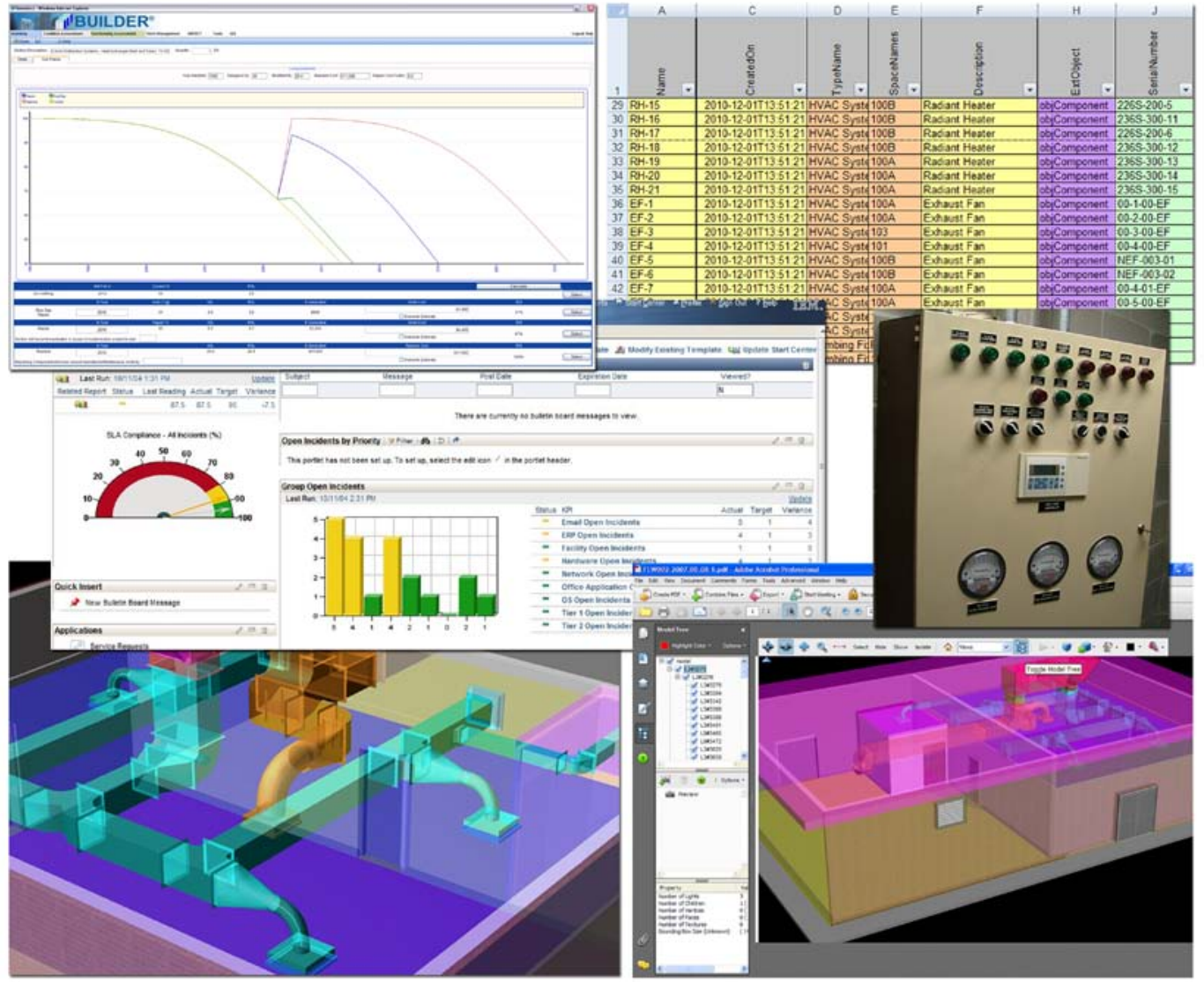





\section{Emerging Challenges and Opportunities in Building Information Modeling for the US Army Installation Management Command}

Beth A. Brucker, E. William East, Lance R. Marrano, Michael P. Case, and William D. Goran

Construction Engineering Research Laboratory (CERL)

US Army Engineer Research and Development Center

2902 Newmark Dr.

Champaign, IL 61822-1076

Allan Carroll and Gus DeJesus

US Army Installation Management Command

2511 Jefferson Davis Hwy.

Arlington, VA 22202

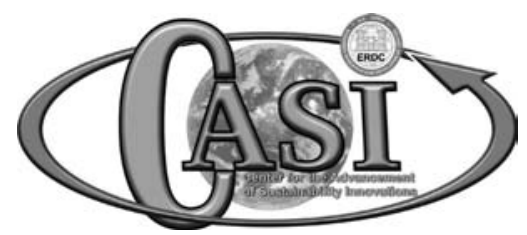

Final Report

Approved for public release; distribution is unlimited.

Prepared for US Army Installation Management Command

Arlington, VA 22202 


\section{Abstract}

Building Information Modeling (BIM) is the process of generating and managing building data during a facility's entire life cycle. New BIM standards for computable building information could serve as the foundation for automation and transformation of many current activities of the US Army Installation Management Command (IMCOM). As with any important emerging technology, a key issue for IMCOM is to decide when it makes economic sense to adopt BIM at the enterprise level. Facilities typically have an expected service life of 50- 75 years, so the availability of upto-date facility data through BIM on a moment's notice represents a great potential benefit to building operators and maintainers. This in turn implies that facility owners and occupants will ultimately have the most to gain from enterprise-wide BIM adoption. The purpose of this report is to help IMCOM to better understand the implications of large-scale adoption of BIM in terms of timing, costs, and benefits. 


\section{Table of Contents}
Abstract ii
List of Figures and Tables...........................................................................................................



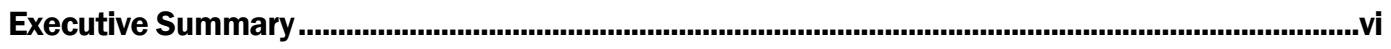
1 Introduction .................................................................................................................................. 1

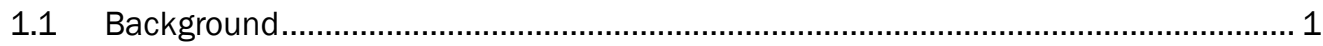

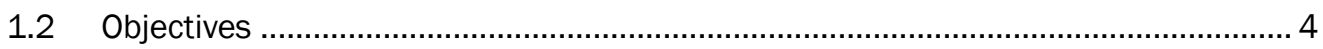

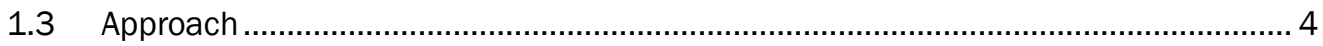

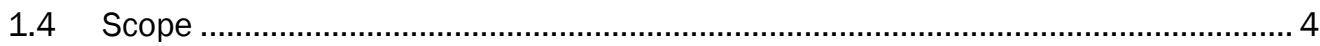

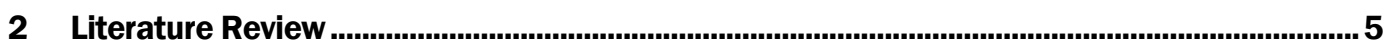

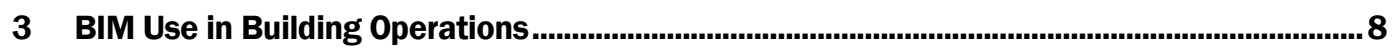

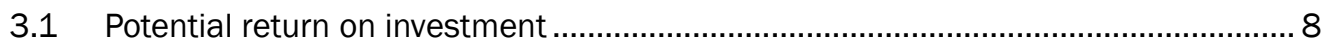

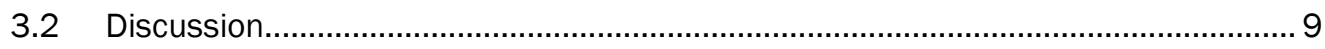

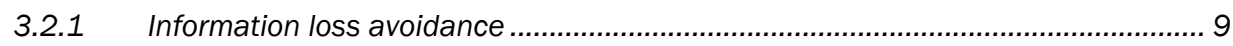

3.2.2 Improvements in data interoperability............................................................ 11

3.2.3 Improved sustainability analysis ..................................................................... 12

3.2.4 Consistent asset inventory data........................................................................ 13

3.2.5 Improved tenant management .......................................................................... 13

3.2.6 Improved visualization of finished building ...................................................... 13

3.2.7 Reduction of wasteful printing, duplication, and mailing .................................... 14

3.2.8 Improved project handover documentation ......................................................... 14

3.2.9 Applicability to existing facilities ....................................................................... 15

4 Low-Risk BIM Opportunities for IMCOM ................................................................................19

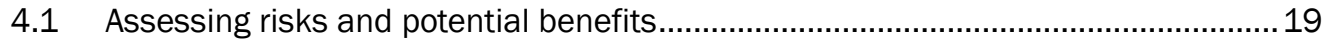

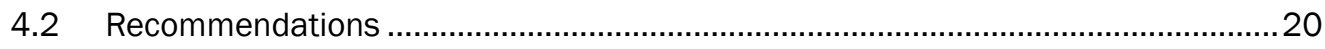

4.2.1 Require BIM execution for all USACE MILCON projects........................................20

4.2.2 Establish IMCOM process for accepting BIM deliverables ................................... 20

4.2.3 Pilot-test emerging BIM standards..................................................................... 22

4.2.4 Prepare managers of legacy systems for BIM technologies ................................. 22

4.2.5 Plan for infrastructure to support integration of BIM with O\&M activities..............23

References .....................................................................................................................................24

Appendix A: Building Information Standards Development..............................................................26

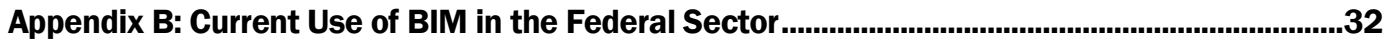

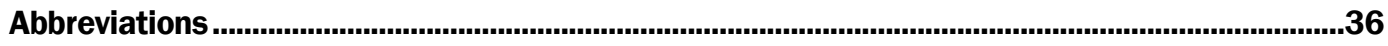




\section{List of Figures and Tables}

\section{Figures}

Figure 1. Facility life-cycle information and installation functions/technologies.................................

Figure 2. Facility handover documentation. .........................................................................................10

Figure 3. Life-cycle information loss. ..................................................................................................

Figure 4. Low-fidelity model (LOD 100).............................................................................................

Figure 5. Medium-fidelity model (LOD 200) .....................................................................................

\section{Tables}

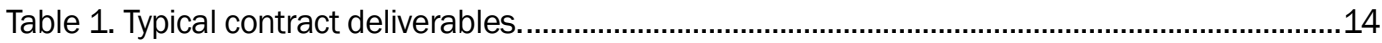




\section{Preface}

This study was performed for the US Army Installation Management Command (IMCOM) under Project, "Systematic Research/ Scanning Support to IMCOM," via Military Interdepartmental Purchase Request MIPR9CERDC1049. The technical monitors were Irene Cruz and Kathleen Vann, IMCOM.

The work was performed by the Engineering Processes Branch (CF-N) of the Facilities Division (CF), US Army Engineer Research and Development Center, Construction Engineering Research Laboratory (ERDC-CERL) in coordination with the ERDC Center for the Advancement of Sustainability Innovation (CASI). At the time of publication, William D. Goran was the Director of CASI and Michelle Hanson was the Associate Director. Donald K. Hicks was Chief, CEERD-CF-N; and L. Michael Golish was Chief, CEERD-CF. Dr. Kirankumar Topudurti was the Deputy Director of ERDCCERL and Dr. Ilker Adiguzel was the Director.

The following individuals are acknowledged for their contributions to the preparation and technical review of this report:

- Claude Matsui, Headquarters, US Army Corps of Engineers (CEMP-CIP)

- USACE Centers of Standardization BIM Managers Group

- Steve Hutsell and Van Woods, US Army Engineer District, Seattle (CENWS-EN-ES-GS)

- Toby Wilson and Stephen Spangler, ERDC Information Technology Laboratory (CEERD-IS-C)

- Susan Nachtigall and Danielle Love, ERDC-CERL (CEERD-CF-N)

- Kayla Kaufman, ERDC-CERL Research Assistant, University of Illinois School of Architecture.

COL Kevin J. Wilson was the Commander and Executive Director of ERDC, and Dr. J effery P. Holland was the Director. 


\section{Executive Summary}

The concept of life-cycle Building Information Modeling (BIM) as a new standard for building information data repositories can serve as the foundation for automation and transformation of many current IMCOM activities. This report summarizes the current state of BIM technologies used in design and construction, outlines the value of BIM for IMCOM, provides an overview of agencies that have adopted BIM, and identifies actions that IMCOM can take in adopting building information technologies and associated standards.

This report does not recommend support for any particular vendor, but describes opportunities where building information and the adoption of open standards can streamline installation activities. The overall recommended approach on BIM is platform neutrality with a commitment to open standards and a focus on the data.

Given the uncertainty surrounding the possible benefits and claims surrounding BIM for owners and operators, this report recommends a number of steps that can be taken with minimal impact to existing short-term business practices, with long-term goals in mind. The following recommendations are for IMCOM's consideration:

1. Request all US Army Corps of Engineers (USACE) MILCON projects be executed and delivered in BIM on projects starting Fiscal Year 2013 and beyond at no additional design fee or project cost.

2. Develop process for accepting BIM deliverables from USACE.

3. Leverage and pilot emerging standards.

4. Engage managers of legacy systems in preparation for future delivery of open standard building information.

5. Plan for information technology infrastructure to enable the integration of building information technologies in operations and maintenance activities. 


\section{Introduction}

\subsection{Background}

Building Information Modeling (BIM) is defined as "a digital representation of physical and functional characteristics of a facility [that] serves as a shared knowledge resource for information about a facility forming a reliable basis for decisions during its life cycle from inception onward" (NIBS 2008). Many see BIM as a new generation of tools to replace Computer Aided Design ( $C A D)$, but that viewpoint is too limited. BIM does address building geometry, but it also encompasses geographic information, spatial relationships, quantities and properties of building components, and potentially much more. BIM involves a process of collecting and managing information gathered during the planning, design, construction, commissioning, and management of a building by many different stakeholders. It does not center on any vendor-specific application, and its widespread adoption will need standards to promote the integration of many diverse technologies through advances in systems interoperability.

Advances in computer technology and business methodologies now make it feasible to envision BIM as an enabling technology for the integration, automation, and transformation of major Installation Management Command (IMCOM) building information data systems and repositories. IMCOM has already applied elements of BIM to many of its functions. Furthermore, many Army enterprise-level systems also incorporate building information. Examples include the General Fund Enterprise Business System (GFEBS), computerized maintenance management systems (CMMS), computer automated facility management (CAFM), geographic information systems (GIS), Capital Planning/ Sustainment Management Systems (SMS), and building automation systems (BAS).

Even with key precepts of BIM in place across IMCOM and the Army, there are many challenges to a fuller integration of BIM into business processes. Perhaps the greatest obstacle to integrating design models, equipment specifications, and control system information has been the lack of uniform digital data exchange standards that may be used by all building life-cycle stakeholders, including architects and engineers, construction contractors, owners, and facility operators, managers, and planners. 
Another challenge is that much building information is duplicated across multiple Army enterprise systems, typically in different data formats that limit the possibilities for integration, interoperability, and standardization. Figure 1 illustrates the nature of these challenges in relation to Army and Department of Defense (DoD) legacy enterprise systems. In a general sense, lines converging from the left to the right indicate the diversity of facility life-cycle information feeding into general categories of legacy information systems; and lines diverging from the left to the right indicate facility information that is included in each type of facility management system. These issues are equally challenging for other federal and nonfederal agencies with which the Army works. The overall data environment is probably even more disjunct than the figure visually indicates.

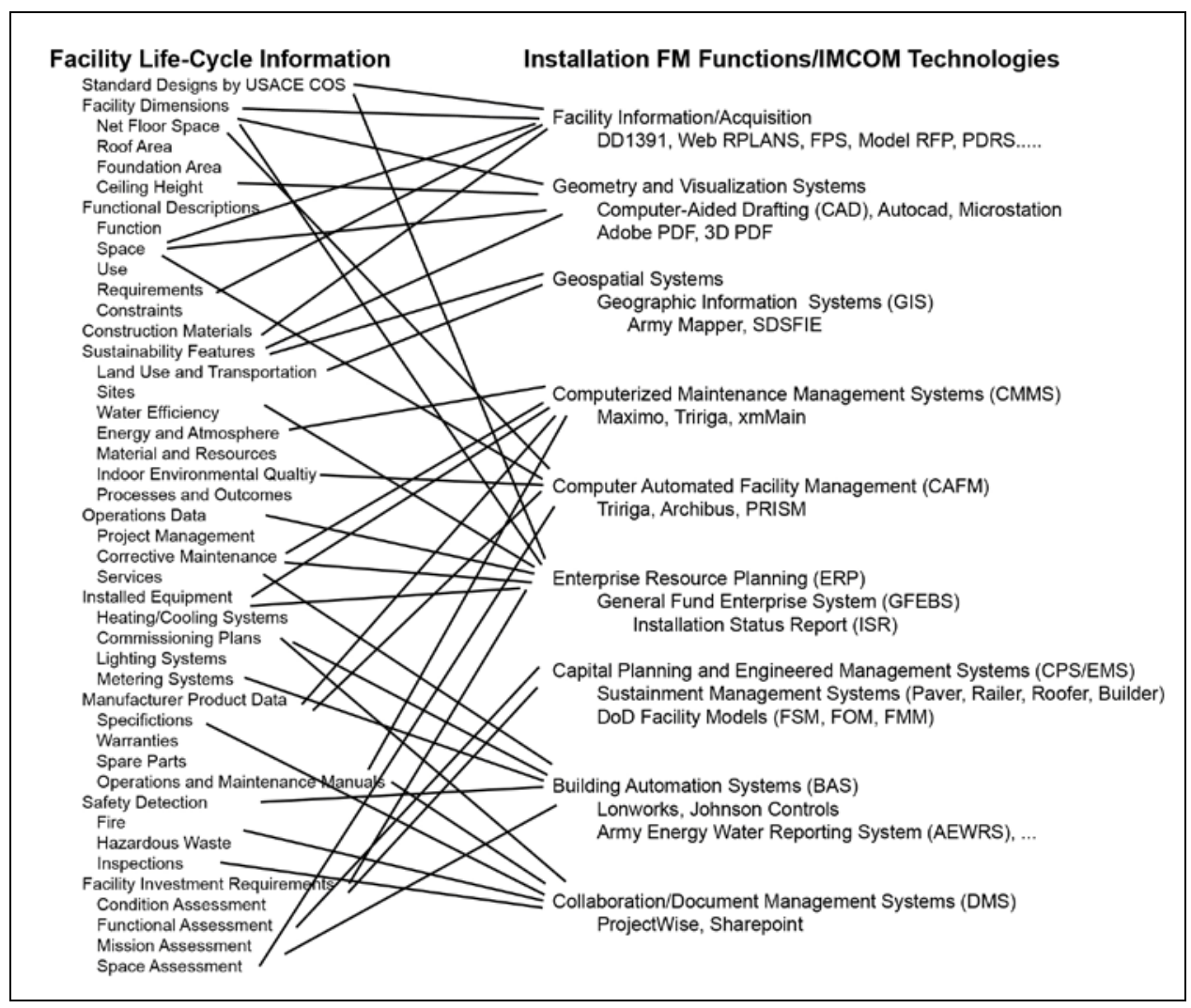

Figure 1. Facility life-cycle information and installation functions/technologies.

Early efforts in promoting data interoperability standards understated the difficulty in achieving consensus among the many stakeholders on required information and data formats.

Many government agencies are supporting and working with industry organizations to develop standards and guidance to overcome the challenge 
of integrating these information technologies over a building's life cycle. These organizations bring together subject matter experts to formalize and build consensus on the development of standards in their specific industries. Major participants in such efforts include the National Institute of Building Science (NIBS) buildingSMART alliance and International Alliance for Interoperability (IAI), the US Green Building Council (USGBC), Construction Specifications Institute (CSI), International Code Council (ICC), Association of General Contractors (AGC), American Institute of Architects (AIA), and the American Society of Heating Refrigerating and Air-Conditioning Engineers (ASHRAE)

Meanwhile, BIM has rapidly gained acceptance throughout the planning, architecture, engineering, and construction industries. Many public and private owners now mandate the use of certain BIM technologies on their design and construction projects. A 2009 survey conducted by McGrawHill Construction on thousands of architectural, engineering, and construction (AEC) project participants in North America found that almost $50 \%$ of the design and construction industry is now using BIM or BIMrelated tools, and that these users plan a significant increase in their use of BIM. This figure represents a 75\% increase in BIM usage over the previous years (McGraw-Hill 2009). Also, colleges and universities have increased BIM curriculum content in the areas of architecture, engineering, and urban design. New professionals are entering the workforce expecting to use BIM technologies in daily practice.

With a "disruptive technology" such as BIM, a large institutional user must carefully consider questions of timing investments to achieve the best possible economic outcomes. Initial costs may deter adoption, but a clear understanding of the benefits will help an enterprise-level user such as IMCOM plan the size and timing of pilot investments. In the case of BIM, these benefits include quantification and management of energy and water use; quantitative analysis of facility portfolios; better understanding of carrying capacity; better ability to align and realign facilities with changing missions; and improved tradeoff analyses for deciding between capital expenditures and facility rehabilitation.

This report focuses on recommendations for Army installations with large facility inventories and well developed technology adoption practices. It is these facility owners that will achieve the most rapid return on investment (ROI) in BIM technologies and have the technical expertise to develop best 
practices that may later be economically adopted by Army operators of smaller facility inventories.

\subsection{Objectives}

The objectives of this work were to assess challenges and opportunities for IMCOM with respect to adopting life-cycle BIM practices and technologies; and to recommend a strategic posture that emphasizes an appropriate return on BIM-related investments by IMCOM.

\subsection{Approach}

This work was based on information collected from the following sources:

1. a review of the technical literature

2. input from US Army and Army Corps of Engineers (USACE) stakeholders

3. industry experts

4. technology providers.

\subsection{Scope}

The recommendations presented here address the implementation of BIM as a long-term facility life-cycle management tool. Issues related to the near-term adoption of BIM design and construction software applications are outside the scope of this report. 


\section{Literature Review}

According to a survey of the design and construction industry, one in five BIM users that measure return on investment (ROI) have documented returns higher than $50 \%$ per dollar spent. That is double the value perceived by BIM users that do not measure ROI (McGraw-Hill 2009).

Architects were the first to realize the benefits of BIM using threedimensional (3D) modeling software that encompasses building geometry, geographic information, spatial relationships, and quantities and properties of building components. The top benefit of BIM reported by architects is improved coordination of documents and drawings, which results in fewer errors and requests for information. They also benefited from better multi-discipline coordination and improved client understanding of design intent when 3D modeling is used. This is significant from an end-user perspective. Often, user-requested changes during construction are caused by a misunderstanding of the facility's intended use, but 3D visualization has been shown to reduce change requirements and their related costs. Also, BIM capabilities to identify clashes or interference in structural components has proven to reduce change orders and rework during construction.

Structural and mechanical, electrical, and plumbing (MEP) engineers are also gaining benefits from BIM. These include reductions in project duration, improved spatial coordination, and visualization for marketing and presentation purposes. Due to the level of detail required by their disciplines, MEP engineers see the highest value in BIM, which for them arises from its 3D clash-detection capability, quantity-takeoff, and costestimation features.

Construction contractors are now the fastest-growing segment of BIM users (McGraw Hill 2009). They are making rapid progress using the BIM design model with simulation and cost-tracking technologies for purposes of construction schedule integration, logistics, activity sequencing, quantity takeoff, estimating, and component prefabrication. BIM-driven prefabrication makes it possible for more building components to be fabricated and finished in controlled factory conditions with less material waste and safer working conditions than possible on the construction site. Contractors are achieving savings through the introduction of tablet computers 
with new BIM-enabled field software. Companies have reported savings of approximately 10 hours per week per user, many adding up to a reduction of 30 days or more off the schedule (Kanner and Omansky 2008).

The use of BIM during construction has focused mostly on the visualization and manipulation of the geometric model components. Large commercial contractors indicate that they often create a model for complex areas within a given project to resolve design discipline coordination problems before construction begins. Manipulation of geometric objects in three dimensions before construction reduces onsite conflicts. According to the Engineering News-Record, 1 hour spent in coordination activities results in 10 hours of saved field re-work (Post 2009). The avoidance of rework reduces time and cost, and helps to ensure that buildings are constructed to specifications without error.

Adding the time dimension to BIM allows the creation of so-called 4D models. The objectives of such models are to visualize sequencing of construction components and to reduce on-site conflicts due to trade scheduling and/ or movement of products in material storage yards. The practical use of $4 \mathrm{D}$ models is most highly visible on time-constrained projects, such as "Bird's Nest" Olympic stadium at Beijing, where the project team used BIM to link building elements with construction sequence (Tekla 2012).

BIM is now being used to facilitate and improve the building commissioning process. During the commissioning process, all of the final documentation and maintenance information related to the facility is transferred to the owner or facility manager. In conventional practice, hundreds or even thousands of documents and drawings are digitally scanned and archived as paper copies in numerous binders that are difficult to store, access, and update. The facility owner ultimately bears the cost of creating this archive. A case study of Maryland General Hospital, Baltimore, MD, found that the use of tablet computers with field software during the construction phase reduced the commissioning process from days to hours. The construction contractor generated a database of all major components and their serial numbers, manuals, warranties, etc. During commissioning, barcodes were added to the components and a unique barcode ID was linked to the database. Commissioning agents then could access all relevant documentation and data for specific pieces of equipment using the tablet computer's barcode scanning software. Further, the 3D BIM model created during the design and construction process is also linked to the 
component barcodes. Therefore, any information about components and equipment can be accessed directly from the 3D model either in the office or the field (Vela Systems 2010). When commissioning is completed, the tablet computer is transferred to the facility management staff for use in ongoing building operations. Work orders can be linked to the component and equipment barcodes so that the 3D model is continually updated as maintenance, repairs, or replacements are made. 


\section{BIM Use in Building Operations}

In an effort to extend the value of BIM beyond the design and construction phases of building life cycle, many facility owners are now requiring that BIM included as a final deliverable. Because facilities have an expected life cycle of 50 - 75 years, BIM's capability to provide current as-operated facility data at a moment's notice offers installation Departments of Public Works (DPWs) an enormous prospective benefit on behalf of facility owners and occupants long after construction has been completed. In order for owners to fully benefit from life-cycle BIM capabilities, however, work will be needed to understand, anticipate, and prepare for incorporating BIM deliverables into the building acquisition and delivery workflow.

\subsection{Potential return on investment}

The main question affecting IMCOM implementation of life-cycle BIM technologies is the amount of real return on investment (ROI). To date there have been few case studies that quantify the ROI on BIM for the building owner. A further limitation on the available ROI information is that no owners with a facility inventory comparable the Army have attempted to implement BIM on a large-scale. The list below summarizes the most promising areas of potential savings for IMCOM. It is followed in the next section by a discussion of the most promising areas of application.

1. Time

a. Increase in staff efficiency to access information (Hardin 2009)

b. Less chance of facility downtime as a result of improper maintenance (Hardin 2009)

c. More-efficient repair response

d. Reduced handover time

2. Money

a. Reduction in wasteful printing and duplication (Hardin 2009)

b. Warranties embedded in the BIM for easy access (Hardin 2009)

c. Keeping equipment maintained to warranty standards (Hardin 2009)

d. Reduced handover cost

3. Information 
a. Ability to back up critical facility data

b. Filing of checklists, manuals, and manufacturer's warranty information in one place

4. Life Safety, Fire Stopping, Accessibility

a. Properly documented commissioning plans and issues (Hardin 2009)

b. Automatic, up-to-date plans for clear navigation through buildings by emergency personnel

5. Client/ Occupant Satisfaction

a. Improved client/ occupant satisfaction (Hardin 2009)

b. Improved living and working environments through better maintenance

c. Reduction of user-requested changes during construction

d. Improved understanding of intended building use.

6. Sustainability

a. Improved tradeoff analysis of different energy and sustainability design

b. Improved capabilities for weighing different designs for energy requirement compliance with EPAct 05, EISA 2007, etc.

\subsection{Discussion}

\subsubsection{Information loss avoidance}

The largest perceived value of life-cycle BIM by owners is having instant access to the as-built/ as-operated building information. One of the largest problems faced by building owners is the huge amount and disorganized nature of documentation provided at the end of the project. This final documentation is often stored in basements or mechanical rooms in nonuniform containers with very little organization for future access (Figure 2). The consequence is a substantial information loss.

The costs of lost or inaccessible data are considerable in terms of lost time in data search, access, and management. According to the National Institute of Science and Technology (NIST), a typical operations and maintenance engineer spends over $40 \%$ of the day searching for the appropriate information and validating it. Another $15 \%$ of the day is often spent track- 
ing down the information necessary to perform maintenance tasks (NIST 2004).

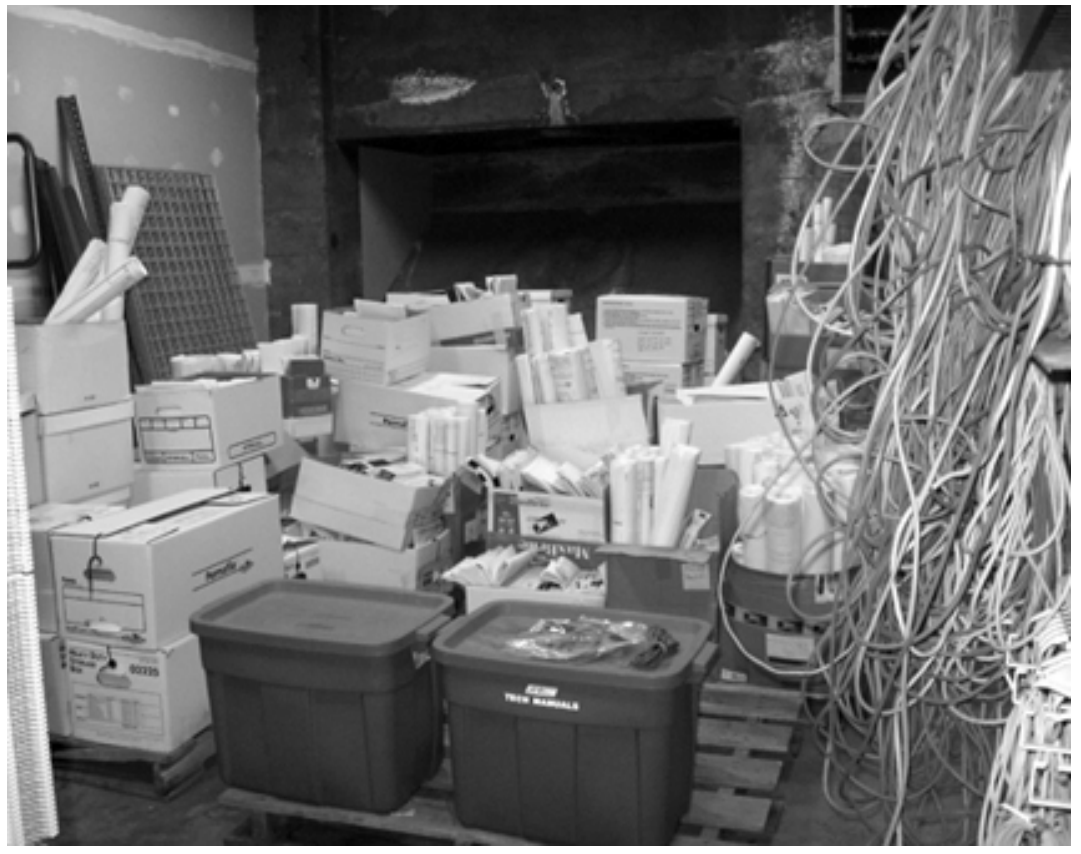

Figure 2. Facility handover documentation.

Currently, information collected during each phase of the facility life-cycle is often lost at the handoff points (Figure 3). Lost information then needs to be at least partially recollected, at additional cost, when needed. The solution provided by BIM is the collection of information as it is generated on a continuous basis. Installations could potentially save considerable time and cost by acquiring usable BIM deliverables from USACE, contractors, and vendors. The current obstacle is a lack of data interoperability standards at the different handoff points shown in Figure 3. 


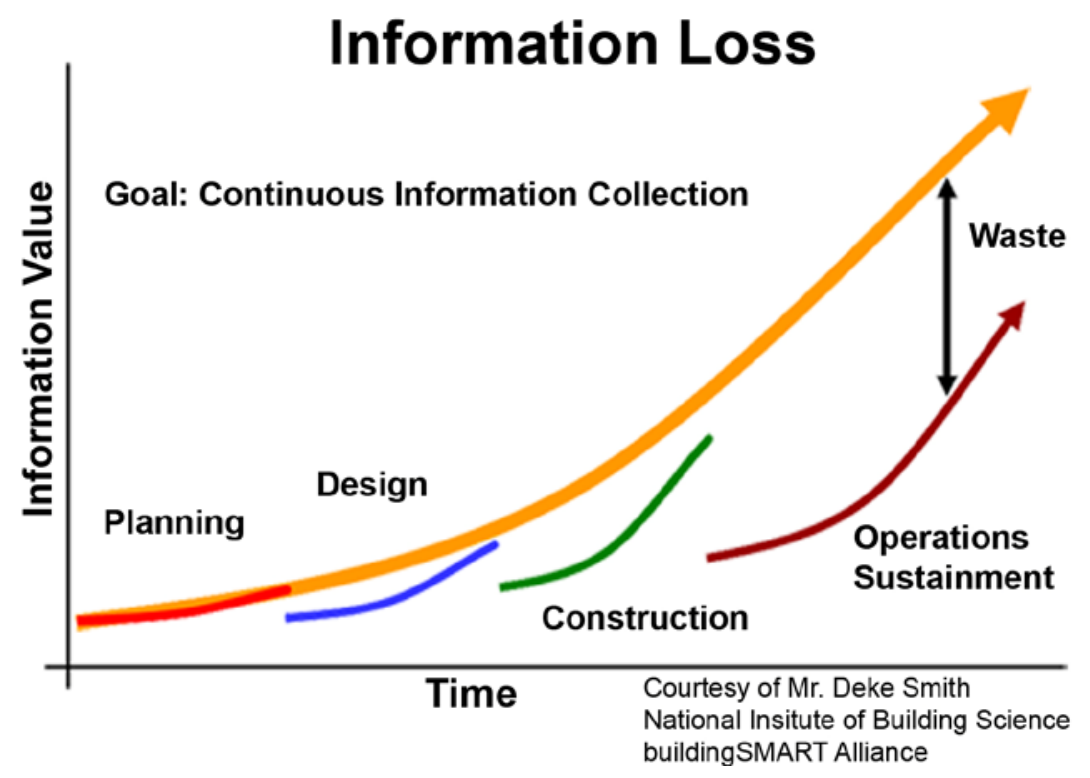

Figure 3. Life-cycle information loss.

\subsubsection{Improvements in data interoperability}

To move toward continuous information collection, data interoperability between life-cycle stages and technologies must be achieved. Interoperability is the ability to manage and communicate electronic data across different systems. The AEC industry has been slow to adopt standards in this area. In 2002, according to the US Census Bureau, the nation had \$374 billion in capital facilities in place. Based on figures from a NIST (2004) study on the capital facilities industry, $\$ 15.8$ billion of that cost, or about $4.2 \%$, could be attributed to data interoperability problems. The authors have found no significant advances in interoperable standards since the date of that study, and consider the NIST results to remain valid.

Using the Fiscal Year 2011 (FY11) Army request of $\$ 50.4$ billion in base discretionary funds for new military construction, operations, and maintenance, and assuming a similar impact as reported in NIST (2004), $4.2 \%$ of that amount - $\$ 2.1$ billion - was lost through inadequate data interoperability. (The impact on final actual expenditures, versus the requested amount that was available at this writing, is expected to be the same in terms of percentage.)

The NIST (2004) results further indicate that $68 \%$ of the costs arising from inadequate interoperability fall on facility owners and operators, and $85 \%$ of that amount is accrued during the operational phase of the building's life cycle. Applying these percentages to the estimated impact on the 
FY11 Army budget (i.e., $\$ 2.1$ billion), we see that the expected cost to facility owners and operators would be $\$ 1.45$ billion, with $\$ 1.23$ billion incurred as part of ongoing O\&M.

The largest cost impact of poor data interoperability during the O\&M phase is related to information verification and validation, or the time spent ensuring that the available information accurately represents the equipment and conditions that are actually in place. Once the information is found, O\&M personnel must spend more time duplicating or transcribing it to required paper or digital formats for distribution to other personnel, creating largely redundant but inconsistent sets of records. These inefficiencies add up to nearly $60 \%$ of the total interoperability costs during the building's operational phase (NIST 2004). Applying these NIST findings to the FY11 request, the Army would be expected to lose nearly $\$ 738$ million to inefficiencies related to duplicated staff effort plus information validation and verification.

The International Facility Management Association (IFMA) has reported similar results, finding maintenance productivity typically ranging from $25-35 \%$, meaning that $65-75 \%$ of the day is spent in unproductive tasks. This inefficiency often can be attributed to waiting on parts, information, drawings, instructions, or work to be completed by other personnel (IFMA CFM Manual).

\subsubsection{Improved sustainability analysis}

The data comprising the BIM model facilitates computerized tradeoff analysis of competing energy and sustainability solutions early in the design phase. Many tools are available to analyze BIM models at this stage (e.g., Green Building Studio, Ecotect, Vasari, and eQuest). These tools make it easier to visualize proposed building alternatives during early design, allowing energy requirements such as EPAct 05 and EISA 2007 to be modeled and analyzed. For example, those responsible for interior lighting can coordinate with those who make decisions about window placement, and then with those who make decisions about building orientation which in turn affects the sizing of mechanical system components. Orientation and roof slope for solar access and photovoltaic (PV) or solar hot water use can be analyzed. Rainwater collection potential and other water conservation strategies can be observed. The BIM model can be moved around the site to optimize and minimize the cut and fill requirements, all these providing immediate feedback and documentation for Leadership in Ener- 
gy and Environmental Design (LEED) certification. In later phases of design, the model can be imported into more robust energy simulation tools such as Energy Plus for refinement.

\subsubsection{Consistent asset inventory data}

Currently, assets are described in an ad hoc manner that does not allow for analysis across the installation, region, or organization. Standardizing asset descriptions and classifications would allow facility management professionals to identify troublesome equipment designs or models and alert personnel responsible for affected equipment. This proactive approach would reduce unplanned equipment downtime, thereby reducing negative impact on mission. In addition, performance data can be used to justify requirements for specific equipment models or designs, thereby providing feedback to the facility design standards group.

\subsubsection{Improved tenant management}

As units are relocated or deployed oversees, often for years at a time, their facilities commonly sit vacant or underutilized. With proper tenant management processes and building information repositories, installations would be able to track underused facilities, promoting greater spatial and functional utilization efficiency.

\subsubsection{Improved visualization of finished building}

BIM tools today allow a building to be fully modeled before construction, reducing and in some cases eliminating design change orders during construction. The complete visualization of a building before construction makes it possible for the installation to better understand the facility that will be built.

The 3D visualization aspect of BIM has many benefits. It enables personnel to ensure that the facility complies with the installation's Form-Based Code, which informs the illustrative and regulating plans that are a subset of the installation's master plan. It ensures that a building fits the form of the area where it is intended to be built. For example, a three-story building should not be built on a street coded for two-story structures. The BIM capability of generating 3D geometry, combined with geospatial viewers (such as Google Earth) and analysis tools (such as those from ESRI), will help the installation avoid wasted design efforts. 


\subsubsection{Reduction of wasteful printing, duplication, and mailing}

Over the past decade, electronic media and portable computing devices have reduced the need for hard copy documents in the field, but the industry still relies heavily on paper documents. For a typical $\$ 8$ million project, an average of $\$ 50,000$ (0.635\%) is spent on printing and shipping hardcopy construction documents and submittals (Systemates 2011). Army projects vary in scope and size, so the $0.635 \%$ figure cannot be used across the board to estimate the cost of Army project hardcopy submittals. However, to look at the saving potential against the Army's FY11 MILCON request of $\$ 6.5$ billion (February 2010) and reducing the percentage to $0.50 \%$, the Army could potentially have saved over \$32.5 million in 2011 by eliminating hardcopy submittals.

\subsubsection{Improved project handover documentation}

Most information needed by the facility manager does not directly concern the geometry of the building. Equipment lists, for example, provide the types and location of equipment plus some limited set of properties. Other equipment properties may be found in the specifications, which comprise a non-geometric representation of building information. The worker installing a pump, for example, does not need to know a detailed geometric representation of that device. They do, however, need to have the installation instructions from the manufacturer, information about the inflow and outflow piping, and the status of the powering electrical system. Table 1 provides a brief list of information currently exchanged in a variety of different documents and messages in many proprietary formats.

Table 1. Typical contract deliverables.

\begin{tabular}{|ll|}
\hline Commissioning Plans & Cost Estimates \\
Daily Reports & Equipment Lists \\
Floor Plans and Drawings & Fabrication Drawings \\
Insurance & Invoices \\
Manufacturer Product Data & Operations \& Maintenance Manuals \\
Photographs & Progress Schedules \\
Quality Control Documentation & Requests for Information \\
Room Data Sheets & Safety Inspections \\
Spare Parts Providers & Specifications \\
Tests and Certifications & Warranties \\
\hline
\end{tabular}


An international panel of experts, facility operators, construction managers, and asset managers participated in developing a standard data framework for the handover of the information contained in typical contract deliverables. This was done under the auspices of a National Building Information Modeling Standard (NBIMS) project by the National Institute of Building Science (NIBS). This standard, now known as the Construction Operations Building information exchange (COBie, East 2007), is emerging as one of the first exchange standards for project handover to operations and management.

Texas A\&M University is currently constructing a Health Sciences Center consisting of a \$68 million health education building, a \$60 million search and education building, and a central utility plant. The university wanted a complete set of building information data at the end of the project for use in CMMS but had not selected a software vendor. The use of COBie on the project provided the university with a vendor-neutral format for documenting building data. This makes it possible to import the data into any CMMS product the university may select. COBie also allows handover data to be collected throughout the project instead of only at the end of construction. Through the use of COBie, the cost for handover of the first building of the Center was $50 \%$ lower than it would have been if the building had to be surveyed after handover (Sawyer 2011).

\subsubsection{Applicability to existing facilities}

The operation and maintenance of Army real property could greatly benefit from the availability of advanced forms of digital as-operated facility data. USACE requires the use of BIM on all new construction projects associated with the Army Standardization Program. However, new construction typically accounts for only a small portion of an installation's real property assets. Current BIM technology is capable of capturing existing facility data, but developing models for all existing facilities is not feasible due to costs and the Army's large inventory of facilities.

The real benefits of obtaining and maintaining life-cycle facility data will not materialize until a significant portion of the new and existing facilities managed by each installation DPW are integrated into a coherent framework. In such a framework, individual documents would no longer be the primary, core representation of a facility. Instead, continually updated data repositories would serve as a shared resource for facility managers to reach reliable, collaborative decisions on building operations. 
As an alternative to developing complete models for existing facilities, a subset of the BIM model could be developed to capture the data needed to improve the cost-effectiveness of operating and maintaining existing facilities. This approach also comes with a cost, according to a study by the University of Washington in 2008 and 2009 that investigated effective methods for capturing BIM data for existing facilities (Rojas 2011). That study looked at how the process could be optimized for use by DPW personnel in daily operations and maintenance as well as real property asset management activities.

The study, conducted in cooperation with the Fort Lewis DPW, also looked at what Level Of Development (LOD), or model-level fidelity, would be needed for operations and maintenance activities. This was done in conjunction with populating COBie data for the selected Company Operations Facility at Fort Lewis. The American Institute of Architects (AIA), Document E202-2008, defines the levels of development as follows:

- LOD 100- Programmatic/ Schematic Design BIM. Essentially the equivalent of conceptual design, the model consists of overall building massing; and the downstream users are authorized to perform whole building types of analysis (volume, building orientation, cost per square foot, etc.).

- LOD 200-Concept Design BIM. Similar to schematic design or design development, the model consists of "generalized systems or assemblies with approximate quantities, size, shape, location and orientation." Authorized uses would include "analysis of selected systems by application of generalized performance criteria."

- LOD 300-Construction Document BIM. Model elements are suitable for the generation of traditional construction documents and shop drawings. As such, analysis and simulation are authorized for detailed elements and systems.

- LOD 400-Fabrication BIM. This level of development is considered to be suitable for fabrication and assembly. The Model Element Author (MEA) for this LOD is most likely to be the trade contractor or fabricator as it is usually outside the scope of the architect's or engineer's services or would constitute severe risk exposure if such parties are not adequately insured.

- LOD 500-As-Built BIM. The final level of development represents the project as it has been constructed-the as-built conditions. The model is suitable for maintenance and operations of the facility. 
A LOD 100 is demonstrated in Figure 4. A LOD 200 is shown in Figure 5. The study calculated the cost of developing a medium-fidelity model(LOD 200 ) to be $\$ 5.82$ for 100 square feet, or $\$ .0582$ per square foot.

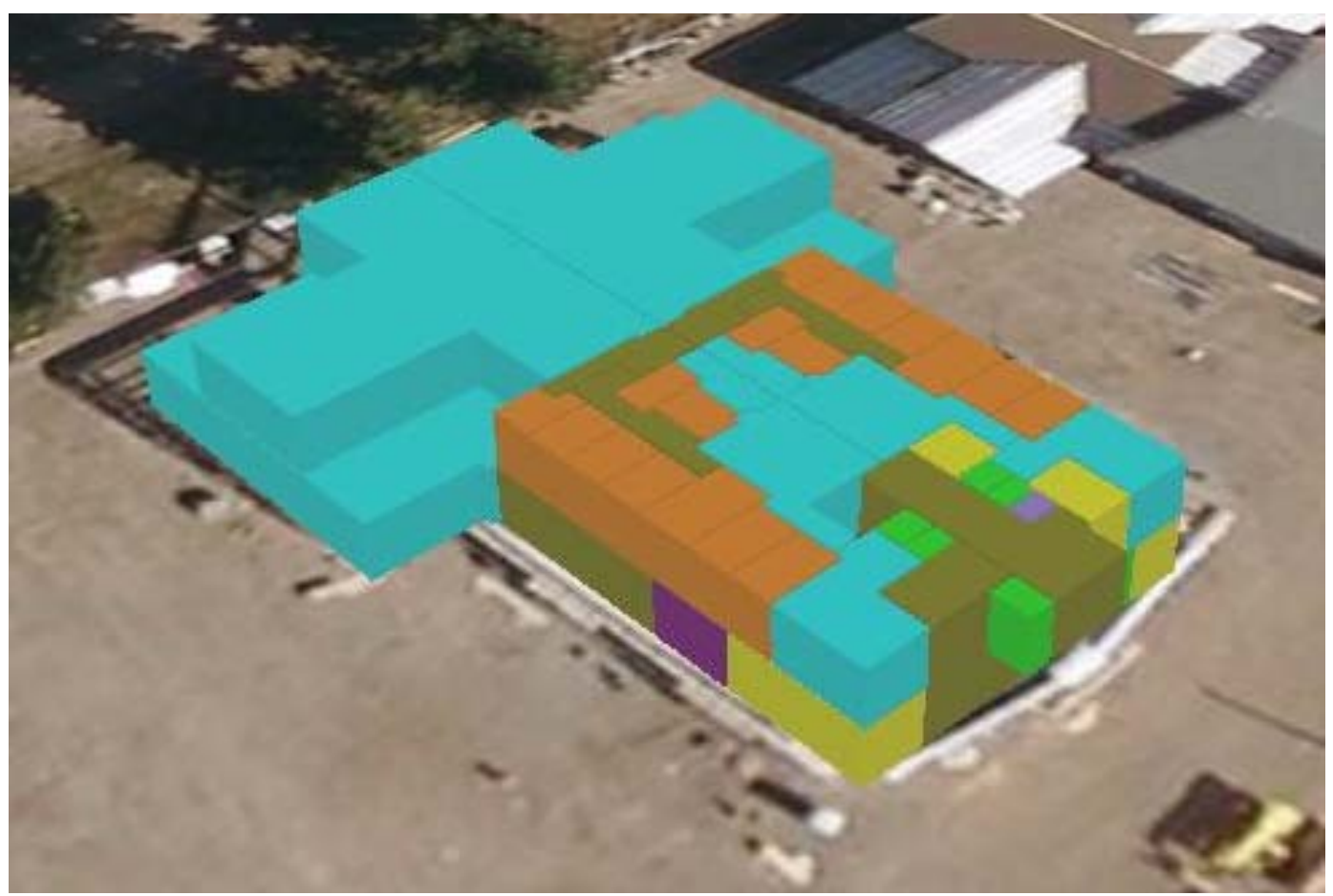

Figure 4. Low-fidelity model (LOD 100).

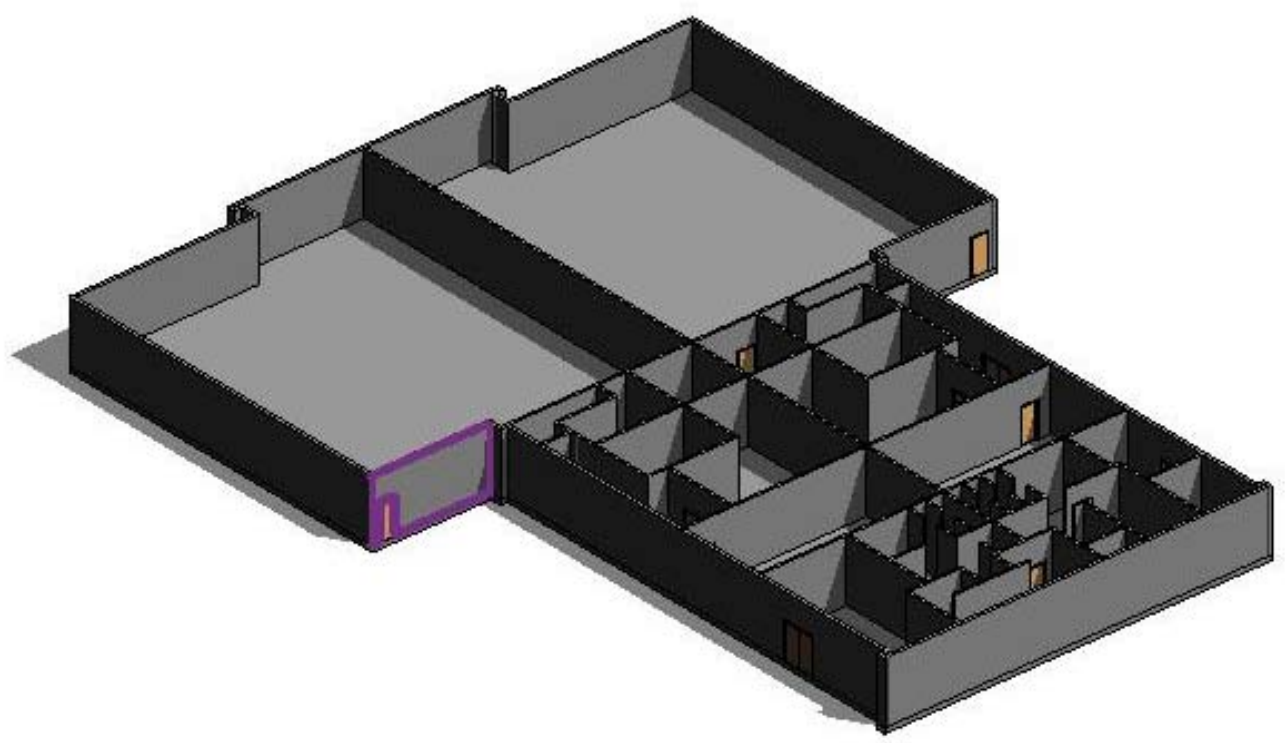

Figure 5. Medium-fidelity model (LOD 200).

This is just one example of an approach to capturing existing facility data. Other technologies, such as light detection and ranging (LIDAR), point 
cloud, 3D scanning, and photo technologies are being used with 3D modeling software to capture as-built conditions for high-fidelity models. These approaches, however, can become quite expensive whether developed in house or by service providers, and would be appropriate only for mission-critical facilities if at all. The level of model fidelity needed for existing facilities must be determined for the many stakeholders at the installation before moving forward. 


\section{Low-Risk BIM Opportunities for IMCOM}

\subsection{Assessing risks and potential benefits}

BIM implementation offers many different potential benefits, but the key to long-term success is to begin with careful, incremental steps. A cautious adoption posture is recommended because these technologies have a great impact on business processes, which must be adapted to continually capture and use the building information.

The value of adopting many innovative technologies, such as the change from incandescent bulbs to compact florescent tubes to light-emitting diode (LED) devices, can be verified using a net present value calculation based on manufacturer energy-consumption ratings. The potential value of BIM cannot be quantified in such a straightforward manner. Consider the example of having correct as-operated building information readily available to maintenance tradespeople: what is the benefit of that to the installation? Does it save the worker a trip to the document library? Does it make it possible to complete more work orders in a single day? What is the value of operating more buildings at rated capacity versus maintaining a higher backlog of preventive maintenance work orders? On an intuitive level it seems logical that having more building information in the hands of DPW personnel and contractors would improve efficiency and reduce costs, but quantifying the benefit is not simple.

It is understandable that DPWs are uncertain about how to begin changing processes and contracts to require building information as a deliverable. A DPW's first responsibility is to keep the installation running, not experiment with a technology that may not deliver the purported benefits given the information systems, contracts, and training that are needed to create, review, and deliver BIM data. Many are justifiably wary of the huge benefits attributed to BIM, understanding much of it to originate in marketing claims by software companies for the purpose of driving sales and upgrades. Given this uncertainty surrounding the real-world benefits to be attained by implementing BIM, the authors recommend a number of steps that can be taken in the near term, with minimal impact on existing business, while keeping longer-term goals in mind. 


\subsection{Recommendations}

\subsubsection{Require BIM execution for all USACE MILCON projects}

Given the benefits and return on investment already documented in the design and construction industry from the use of current BIM technologies, IMCOM should request that all appropriate USACE MILCON projects be executed and delivered in BIM starting with FY13 projects at no additional design fee or project cost. USACE is already committed to implementing BIM for the Army Standardization Program, and the USACE Centers of Standardization are beginning to use BIM in an adapt-build process for reuse of designs and models. IMCOM can work with the Districts to set priorities.

Contract language requiring specific BIM submittals should be used. "Attachment F - Building Information Modeling Requirements, Section 0133 16," developed by USACE and its industry partners, should be reviewed to ensure that it meets IMCOM needs. BIM models should include all disciplines, and contractors should be required to develop a project execution plan describing how they will meet the BIM submittal requirements. IMCOM should begin with the USACE BIM "Project Execution Plan Template" and modify it as needed.

Many available software tools can be used for advanced analysis on a BIM model. IMCOM should consider requesting that early design energy modeling be performed on select FY13 projects. These tools make it possible too incorporate new energy requirements (e.g., ASHRAE 189.1) into the BIM environment for advanced simulation and analysis. This approach will allow IMCOM to consider many alternative designs for purposes of weighing tradeoffs between different sustainability solutions. The models can be used later to verify compliance with sustainability and energy mandates.

\subsubsection{Establish IMCOM process for accepting BIM deliverables}

IMCOM should establish the requirement for the delivery of openstandard BIM deliverables on all MILCON projects irrespective of any future decisions about the final repository for life-cycle BIM data. Four BIM delivery specifications being used today-Adobe Acrobat 9.0 3D PDF, Industry Foundation Class (IFC), the Construction Operations Building information exchange (COBie), and select geospatial data in SDSFIE 3.0- 
could be delivered by USACE from the BIM environment to the installation. These four delivery specifications are a byproduct of current BIM technologies and should be requested from USACE at no additional cost.

A commercial off the shelf (COTS) solution that could be used today in a variety of different settings is the 3D PDF building model provided through Adobe Acrobat 9.0. Because Adobe Acrobat Reader is an essential component of the Army IT environment, the use of 3D PDF is highly recommended over the many other open-source or proprietary model viewing applications. The BIM tools currently used by Districts have the necessary export capabilities to produce 3D PDF files. It is recommended that IMCOM develop submittal requirements for 3D PDF files at different stages and uses of Design-Bid-Build and Design-Build contracts.

Delivering relevant, uniformly organized electronic building information is the primary objective of the international open standard for the delivery of facility management handover information, which includes COBie and related standards being developed for building information requirements such as equipment specifications and layout, utility systems, etc. The COBie data format provides a complete digital set of all scheduled building products and equipment (i.e., real property and personal property), a complete list of all rooms with room type and dimensional information, and a complete set of attached spares, parts, and product manuals. Many COTS software tools are beginning to support the delivery of COBie information, which inherently includes such information as National Fire Protection Association (NFPA) fire escape, evacuation plan, and equipment location calculation for each space.

Many current BIM platforms have the ability to export SDSFIE 3.0 data such as building footprint. IMCOM and USACE should determine which data elements from each platform BIM and GIS could be beneficially exchanged, with attention to which organization is responsible for producing and maintaining the authoritative data sources.

IMCOM staff and installations should reach out to their regional Engineer District to help further define deliverables that BIM technologies can provide. Installations should be familiar with the BIM Manager at their Engineer District office, who can address questions and concerns. IMCOM and USACE should foster this relationship as adoption of BIM deliverables by installations proceeds. 


\subsubsection{Pilot-test emerging BIM standards}

It is recommended that IMCOM participate in the development of BIM standards to ensure the emerging standards meet the Army installation requirements. As new standards are accepted and incorporated into BIM technologies, IMCOM should pilot-test them at select installations through demonstration programs such as the Installation Technology Transition Program (ITTP) and the Environmental Security Technology Certification Program (ESTCP). These early-adopter installations should be selected on the basis of having compatible acquisition processes in place and personnel who require little or no training in migrating to new BIM standards.

ITTP is sponsored by the Office of the Assistant Chief of Staff for Installation Management (OACSIM). The program promotes innovative, costeffective technologies that improve installation infrastructure design as well as life-cycle operation, maintenance, and sustainability through field testing and demonstration. ITTP is managed by the Technology Standards Group (TSG), a component of the Army Facilities Standardization Program. The TSG provides a systematic process for the evaluation and implementation of innovative technology in support of the Army's installation management mission. The TSG identifies requirements, prioritizes projects, reviews demonstration results, and recommends new technology standards to the Army Facilities Standardization Committee (AFSC) for inclusion in the Installation Design Standards (IDS).

ESTCP is managed at the Defense level, with the ESTCP Director reporting to the Installations and Environment secretariat office. ESTCP funds technology demonstrations for issues that are shared across the military services.

\subsubsection{Prepare managers of legacy systems for BIM technologies}

Coordination with legacy systems such as RPLANS, GFEBS (IFS), Sustainment Management Systems (SMS), etc. is vital because these systems provide mission-critical data for upward reporting and management of the installation's assets. This information is used to define and verify facility deficits and reports to HQIIS for justification of installation sustainment funding.

Software upgrades of legacy systems represent significant investment of time and effort, and therefore require good planning and sufficient fund- 
ing. The managers of these legacy systems should be directly engaged in this process as BIM standards continue to be developed in order to ensure that existing Army data requirements are fully met.

\subsubsection{Plan for infrastructure to support integration of BIM with O\&M activities}

Many new technologies such as remote sensing and metering, broadband wireless mobile devices, tablet computers, radio-frequency identification (RFID) tags, and advanced sensors and controls should be considered as BIM technologies are adopted. Over the long-term, an installation's IT infrastructure will support the automatic transmittal of data to building information repositories (or life-cycle BIM repositories). When considering a BIM adoption plan and the resources that will be required to maintain these data repositories, IMCOM should carefully consider emerging technologies such as Energy Management Control Systems (EMCS, BAS), which can reduce human interaction with data warehousing and maintenance, and proactively plan to integrate these technologies. 


\section{References}

American Institute of Architects. 2008. Building Information Modeling Protocol Exhibit. Document E202-2008. Washington, DC: American Institute of Architects.

buildingSMART alliance. http://www.buildingsmartalliance.org/.

Department of Defense. "Fiscal Year 2011 Budget Request: Overview." February 2010. Washington, DC: Department of Defense.

East, E. William. 2007. Construction Operations Building Information Exchange (COBIE). ERDC/ CERL TR-07-30. Champaign, IL: US Army Engineer Research and Development Center, Construction Engineering Research Laboratory (ERDC-CERL).

East, E. William. 2009. “Performance Specifications for Building Information Exchange.” J ournal of Building Information Modeling. Fall 2009: 18-20.

Gallaher, Michael P., Alan C. O’Connor, J ohn L. Dettbarn, Jr., and Linda T. Gilday. August 2004. "Cost Analysis of Inadequate Interoperability in the US Capital Facilities Industry.” Technical Report No.: NIST GCR 04-867. Gaithersburg, MD: Building and Fire Research Laboratory, National Institute of Standards and Technology.

Hardin, Brad. 2009. BIM and Construction Management - Proven Tools, Methods, and Workflows. Wiley Publishing, Inc.

Kanner, J osh, and Adam Omansky. 21 October 2008. "Field Software + Tablet PCs = Construction Field Productivity (Finally)." Viewpoint: Workplace.

Lee, G., R. Sacks, and C. M. Eastman. 2006. “Specifying parametric building object behavior (BOB) for a building information modeling system." Automation in Construction 15(6): 758-776.

National Institute of Building Sciences. http://www.nibs.org/index.php.

Post, Nadine M. 2009. “Modeling Pathfinders Impatient to Have a Much Fuller Digital Toolbox." Engineering News-Record 262(7): 30-34.

Rojas, Eddy, Carrie Dossick, J ohn Schaufelberger. 2010. “Evaluating Alternative Methodologies for Capturing As-Built Building Information Models (BIM) for Existing Facilities. ERDC/ CERL CR-10-1. Champaign, IL: ERDC-CERL.

Rojas, Eddy, Carrie Dossick, J ohn Schaufelberger. 2010. “Developing Best Practices for Capturing As-Built Building Information Models (BIM) for Existing Facilities. ERDC/CERL CR-10-2. Champaign, IL: ERDC-CERL.

Sawyer, Tom. 7 March 2011. "Data for the Life Cycle." Engineering News-Record, 266(7): 26-32. 
Schwenk, David M., J oseph Bush, and David M. Underwood. August 2005. "Heating, Ventilating, and Air-Conditioning (HVAC) Control Systems Operations and Maintenance at Fort Bragg, NC." ERDC/ CERL TR-05-14. Champaign, IL: ERDCCERL.

"SmartMarket Report: The Business Value of BIM, Getting Building Information Modeling to the Bottom Line." 2009. McGraw-Hill Construction.

Systemates, Inc. 2011. "Cost Analysis for a Typical \$8 million Construction Project." http://www.projectmates.com/Portal2007/Products/SubmittalCosts.pdf. Accessed 26 J anuary 2012.

Tekla. 2012. Olympic Stadium, Beijing, China, Tekla Structures. www.tekla.com/ us/solutions/references/Pages/OlympicStadium.aspx. Accessed 26J anuary 2012.

US Army Engineer District, Baltimore. 19 March 2008. "MILCON: Meade Prepares for New Tenants." Army.Mil.News. http://www.army.mil/-news/2008/03/19/8010-milconmeade-prepares-for-new-tenants/.

Vela Systems. 2010. Case Study: Maryland General Hospital. Connecting BIM to Commissioning, Handover and Operations. Burlington, MA: Vela Systems.

National Institute of Building Sciences. “Whole Building Design Guide.” Accessed 5 March 2012. http://www.wbdg.org/.

National Institute of Building Sciences. 2008. "Building Information Modeling." Last modified 24J uly 2008. http:// www.wbdg.org/ bim/ bim.php.

http://www.cis2.org/index-bak.htm

http://www.sdsfie.org/Home/tabid/38/Default.aspx 


\section{Appendix A: Building Information Standards Development}

Many government agencies are supporting and collaborating in the development of building information standards and methods for integrating them into building life-cycle management. Key private-sector and nongovernment organizations involved in developing these standards include the National Institute of Building Science's buildingSMART alliance and International Alliance for Interoperability (IAI), the US Green Building Council (USGBC), Construction Specification Institute (CSI), International Code Council (ICC), Association of General Contractors (AGC), American Institute of Architects (AIA), and the American Society of Heating Refrigerating and Air-Conditioning Engineers (ASHRAE).

This appendix outlines several standards for IMCOM to be aware of in relation to initial BIM-adoption activities. Some of these standards are in place and being used in practice today, but others are still in early phases of development and testing.

\section{Spatial Data Standards for Facilities, Infrastructure, and Environment}

The Spatial Data Standards for Facilities, Infrastructure, and Environment (SDSFIE) is a single DoD spatial standard that supports common implementation of all defense business missions, i.e., installations, environment, and civil works missions. Now recognized as an enterprise standard in all DoD business missions, SDSFIE is managed by the Defense Installations Spatial Data Infrastructure (DISDI) Group, which reports to the DoD's Installation \& Environment Investment Review Board.

SDSFIE development was originally seen as a technical activity at the project level. But given its new role as an enterprise-level standard, the DISDI Group developed a vision and a strategy to completely re-engineer the standard. The latest version, SDSFIE 3.0, is a logical data model that can adapt to DoD business requirements, processes, and other needs. SDSFIE 3.0 will also become an integral part of the data standards used in the National Systems for Geospatial Intelligence (NSG). 


\section{CIMsteel Integration Standard}

The CIMsteel Integration Standard (CIS) was developed to facilitate easy information exchange between the planning, design, analysis, and construction phases of steel-framed buildings and similar structures. This set of specifications identifies what information can be transferred and how that information must be structured in an exchange file. Most importantly, CIS facilitates an integrated method of working, enabling engineering software vendors to make their applications mutually compatible. This allows the software users to exchange data easily from one application to another. The second edition of the standard, CIS/ 2 , extends the engineering scope and further enables information exchange with advanced data management capabilities. In addition to the ability of CIS to facilitate seamless information exchange, CIS/ 2 allows software vendors to support more direct methods of information exchange for coordinated engineering.

\section{gbXML}

Green Building Extensible Markup Language (gbXML) was developed for energy analysis early in the design process. By incorporating XML, the standard is designed to promote interoperability, and transformation methods have been developed to move information freely between gbXML and Industry Foundation Classes (see below). This harmonizes exchange requirements of gbXML and LEED within the context of an EnergyPluscompliant Model View Definition (MVD) so a comprehensive view of the information can be defined. These exchange requirements are extensive, but the use of BIM models is expected to be increasingly important.

\section{NIBS-developed information exchange standards}

NIBS is an independent nonprofit organization that facilitates between the government and private sectors to develop information exchange standards. The buildingSMART alliance is a council of NIBS whose mission is to promote collaboration, technology, integrated practices, and open standards to improve infrastructure life-cycle management. It helps BIM users from all sectors by providing digital tools for sharing up-to-date building information throughout the life cycle of the facility. Below is a list of projects currently in development through the buildingSMART alliance. 
IFCs: An Industry Foundation Class (IFC) model is an object-oriented data file format that describes and simplifies building information so that it can be easily exchanged between planning, design, and construction industries. It is a vendor-neutral open specification that was developed to facilitate interoperability within the building industry. IFC model data can be exchanged between multiple parties using various software programs without the need to repeatedly reformat the information.

CVie: The Coordination View information exchange (CVie) project was created to help resolve clashes in design coordination. However, the CVie was not designed to allow full BIM models to be exchanged between multiple BIM systems. Physical objects remain part of the permanent project, and the Coordination View contains only the information needed to detect any physical collisions between those objects. The Coordination View was one of the first IFC Model View Definitions (MVDs), and it remains the most widely implemented types of IFC exchange. Commercial software certification under the IFC model has been taking place for a decade through the Model Support Group of the IAI.

COBie: In the conventional design and construction process, building information must be reformatted each time it is handed from the designer and manufacturer to the builder to the commissioning agents. The handover information created through this inefficient process is largely in the form of disorganized paper files that may have both numerous redundancies and gaps, and it is virtually useless to the facility owner and operations personnel. The Construction and Operations Building information exchange (COBie) is an information exchange format designed to simplify the capture and delivery of building life-cycle information for facility managers. COBie information is added as it is created during design, construction, and commissioning. In each phase of the project, the COBie specification identifies the information that must be captured and exchanged. The designer provides the space layout, system list, and the types and location of equipment. The builder adds the equipment make, model, and serial number, and provides manufacturer literature, warranty and replacement parts information. The commissioning agent provides the job plan data with associated tools, training, and equipment requirements. After facility handoff, operations and maintenance managers can import the COBie information directly into their asset and maintenance data, using either IFC or simple spreadsheets, to greatly facilitate maintaining, operating, and tracking the condition of the building. 
COBie information can be displayed in several different formats to accommodate the needs of the various stakeholders, who typically interact with COBie using different kinds of software. Each display format provides a completely interoperable view of the underlying information specified using COBie. The information can be viewed in design, construction, and maintenance software or in simple spreadsheets. This versatility allows COBie to be used in all projects regardless of size and technological sophistication.

\section{Standards in development}

QTie: The goal of the Quantity Take-off information exchange (QTie) project is to create nonproprietary specifications for delivering facility information. It was specifically developed to help reduce waste in three types of problems encountered by cost estimators and other members of the project team: Quantity Take-off for Counting, literally counting the components and covering items in a project; Quantity Take-off for Quality, or pricing the components based on their quality; and Quantity Take-off for Methods, or understanding how the contractor will build it. Those using QTie-compliant BIM technology will be able to work faster and with better quality. The standard will ensure that regardless who originally developed the estimates, the data may be used confidently without the need to recount and recalculate.

SCie: Most projects begin with the creation of an architectural program, outlining the scope and the function of the proposed building, and justifying the request for funds. As the project progresses, there is sometimes pressure to expand the scope while keeping funding constant, which can result in completed buildings that do not function as originally intended. The Spatial Compliance information exchange (SCie) allows the architectural program to be created based on the scope of a specific project. This information is used to track the project from concept through completion and management of the facility assets to ensure compliance with the original program. Only three sets of building data-space function, space area measurements, and zoning - are needed to track spatial compliance with the original design. Because spatial program compliance data are required in construction handover documents, the data required for SCie are already present in the COBie specification. As a result, SCie data can be captured through the use of COBie in any of its spreadsheet- or IFC-based implementations. 
ELie: In addition to the delivery of space and equipment lists through COBie, an important additional set of facility handover information is equipment layout drawings. These drawings are available during commissioning, but are often lost and almost immediately outdated. The Equipment Layout information exchange (ELie) project is developing an open format for the exchange of isometric equipment and connection diagrams and providing a common layout for piping schematics. ELie takes into account work already accomplished by the process plant industry as well as information that describes building blocking and stacking diagrams contained in COBie. This effort bridges current projects being conducted at FIATECH (ISO 15926) with contributions of the buildingSMART alliance (ISO 16379). The result of this initial effort can be implemented through an amendment of UFGS facility handover specifications that requires the delivery of one paper copy of ELie information for mounting in the mechanical room, and an electronic copy that may be maintained and updated by the DPW. Further information exchange efforts are addressing the exchange of schematic water system information through the COBie format, including potable water supply, waste water, and possible gray water handling, possibly using the same information exchange format as ELie.

SPie: The Specifiers' Properties information exchange (SPie) is a collection of open-standard property sets for materials, products, and equipment. Its purpose is to reduce the effort expended by individual project teams and to ensure that owners do not impose conflicting property set requirements. The templates provide examples of the kinds of decisions that specifiers often make as they identify the required quality of materials, products, assemblies, and systems identified in the specifications. This project, which received the 2010 Excellence in Construction Information Award for Innovation from CSI, brings together designers, specifiers, trade associations, and manufacturers to create a sustainable basis for the specification of standard product templates, and the publication and use of manufacturers' filled-in product data. Efforts currently focus on capturing performance requirements for electrical equipment in cooperation with the National Electrical Manufacturing Association (NEMA). As this project proceeds into other building product areas, the information may be passed to DPWs via the COBie format. In addition to performance information, other types of information that may be added to SPie for capture within COBie include manufacturer's parts lists, manufacturer warranty terms, and recommended maintenance procedures. 
ENERGie: The Energy Information Exchange (ENERGie) project is intended to define the life-cycle energy analysis information that must be exchanged between the design team and the energy analyst or LEED assessor. Much of the information required for energy analysis is created by architects, structural engineers, and other project team members during the design phase. The ENERGie project also looks at how the energy output from systems and components can be captured When that information is captured and shared with energy analysts, the time and effort required to collect, check, and analyze the data is dramatically reduced. The project builds on previous work sponsored by General Services Administration through the OGC/ AECOO test bed on energy analysis during the early design stages of a project. The ENERGie project is also investigating energy analysis requirements to support LEED assessment and identifying particular information exchange requirements that can be supported from BIM systems using IFC. 


\section{Appendix B: Current Use of BIM in the Federal Sector}

Other public-sector agencies are at varied stages of BIM adoption. Following is a quick overview of the more notable use of BIM in the public sector.

\section{US Army Corps of Engineers}

In March 2005 USACE established a team to investigate the potential of BIM and make recommendations for an adoption strategy. On 6 March 2006, a USACE Memorandum entitled "Realignment/ Establishment of Centers of Standardization (COS)" assigned responsibility to the COS for developing or maintaining BIM models for standard facility types.

In October 2006, the Engineer Research and Development Center (ERDC) published Building Information Modeling (BIM): A Road Map for Implementation to Support MILCON Transformation and Civil Works Projects within the US Army Corps of Engineers (ERDC TR-06-10). This document outlined the goals, objectives, and schedule for BIM adoption by USACE. A draft 2012 update of the roadmap has been prepared.

The first goal of the USACE Roadmap was to establish an Initial Operating Capability (IOC) at the eight USACE MILCON Centers of Standardization by the end of 2008. This push was to gain experience in BIM by implementing the technology on selected standard designs in support of the Army's MILCON Transformation program. A brief survey of 15 Corps Districts in October 2009 found that over 142 projects had been completed in BIM by those Districts. These projects were completed by in-house and/ or $\mathrm{AE}$ contract BIM teams.

Getting Corps Districts prepared for BIM required a varied set of tools and skills. Although BIM stems from traditional processes, it represents a new business process for facility acquisition and delivery. BIM education, training, technology acquisition, data and standards were key components in establishing the Corps IOC. A corporate dataset of BIM objects was developed for the Corps districts and their Architectural and Engineering (A/E) partners. BIM training was established for District architects and engineers as well as specialized workshops for District BIM Managers. 
This training was funded through an Enterprise License Agreements (ELA) and through contracts administered by ERDC's CAD-BIM Technology Center.

Beginning in 2006, USACE worked with a group of BIM-aggressive firms in conducting discussions and workshops on mutually beneficial BIM issues. This USACE/ Industry BIM Advisory Committee is a multi-platform mixture of users that collaborate on best practices, contract language, standards, and other topics that provide a tremendous opportunity to partner in the strengthening of federal and private sector BIM initiatives. The committee participation is strictly voluntary and has expanded to include design, construction, academia, and legal professionals

The Committee developed Attachment F - Building Information Modeling Requirements for Section 013316 - Design After Award. The contract provisions are helping to implement current BIM best practices on a wide range of public works projects. These BIM requirements are actively being refined as projects are implemented and best practices are emerging in the industry.

A key focus area of the USACE Roadmap is a move towards vendor neutrality through open information exchange standards. USACE is planning pilots of the Construction Operations Building information exchange (COBie) standard in FY13. If successful, COBie would become a required deliverable in FY13 or FY14.

\section{Army Reserve}

Army Reserve is using BIM on all full designs and has fully integrated BIM into their design process. They are now exploring the use of BIM in construction and $\mathrm{O} \& \mathrm{M}$. The A/E's are using BIM to show "walk thrus" in the buildings. Completed a pilot project, Raleigh, with BIM as-builts and the delivery of some of the $\mathrm{O} \& \mathrm{M}$ data to the user in BIM format and are gathering feedback and lessons learned for future incorporation.

They have recently completed their "Army Reserve BIM SOP", which outlines the use of BIM on projects and lays out the vision for ultimate incorporation of BIM into construction and O \& M. The BIM SOP was done in collaboration with PM, ED and ACSIM-ODR. Through their Configuration and Control Board (CCB) process, they are working with their Reserve Support Centers (RSC's) on what their O \& M data needs are and how they 
can improve deliverables. BIM has been part of that discussion. The AR requires the use of the Projnet Submittal Register to begin collecting electronic $\mathrm{O} \& \mathrm{M}$ data, with BIM ultimately providing the initial framework. Their AR customer at the RSC and facility level does not use BIM so they are focusing on how to use BIM to deliver the data in a format they can use rather than simply providing the BIM model.

\section{State Department}

The Bureau of Overseas Buildings Operations (OBO) of the US State Department is responsible for OCONUS embassy construction. OBO's transition to BIM was based on feedback received from designers and builders received several years ago. At that time a number of designers and contractors indicated that they used BIM without having been directed to do so by OBO. The purpose of this effort was to reduce potential physical collisions of building components in the field. Based on that feedback, OBO proceeded with new standard designs and design contracts that incorporated BIM requirements.

For the past two years, OBO has required the use of BIM on their projects. In addition, OBO has required the delivery of COBie data with each design deliverable. The track record on these projects has been mixed. This is partially due to insufficient specifications for determining the expected quality of the BIM deliverable and partially due to the inability of all IDIQ designbuild firms to incorporate integrated design workflows into their professional practice.

The OBO's Chief Information Officer's (CIO) office is currently looking at $\mathrm{BIM}$, and COBie format in particular, to integrate all its facility related systems.

\section{General Services Administration}

In 2003 the General Services Administration (GSA), through its Public Buildings Service (PBS) Office of Chief Architect (OCA), established the National 3D-4D BIM Program. GSA was the first federal government organization to require BIM deliverables on their projects. GSA's OCA was responsible for these guidelines that included a significant portion of GSAproprietary requirements. Although open standard Industry Foundation Class (IFC) models were used as the basis for the deliverables, the files provided could not be easily adapted to other agencies. GSA-specific space 
measurement, classification, and other requirements were developed through IFC interfaces in commercial software. More information on the GSA BIM initiative can be found at http://www.gsa.gov/bim.

\section{Department of Veterans Affairs (VA)}

In April 2010 the VA released their building information lifecycle vision and BIM guide. In this guide they issue "instructions that Industry Foundation Classes (IFC)-compliant BIM authoring tools be used at the $\mathrm{AE}$ software for all major construction and renovation projects (capital projects appropriated at over $\$ 10 \mathrm{M}$ ) starting design in FY2009. The VA has also adopted COBie as the "methodology to electronically transfer building information after construction in complete for facilities management. More information on the VA BIM Guide can be found at http://www.cfm.va.gov/til/bim/BIMGuide/lifecycle.htm.

\section{US Air Force}

The Air Force Center for Engineering and the Environment (AFCEE) currently has a draft BIM plan (BIM Flight Plan) out for review. AFCEE is pursuing an adapt/ build program much like the USACE Standard Building Design.

\section{National Aeronautics and Space Administration (NASA)}

NASA is currently preparing their BIM guidance.

\section{US Navy}

Navy NAVFACENCOM is currently evaluating BIM for application to its many business lines, including asset management, sustainment management, public works, etc. 


\section{Abbreviations}

$\begin{array}{ll}\text { Term } & \text { Definition } \\ \text { ACSIM } & \text { Assistant Chief of Staff for Installation Management } \\ \text { ANSI } & \text { American National Standards Institute } \\ \text { AT/FP } & \text { antiterrorism/force protection } \\ \text { CEERD } & \text { US Army Corps of Engineers, Engineer Research and Development Center } \\ \text { CERL } & \text { Construction Engineering Research Laboratory } \\ \text { COBie } & \text { Construction Operations Building information exchange } \\ \text { CONUS } & \text { Continental United States } \\ \text { DASA } & \text { Deputy Assistant Secretary of the Army } \\ \text { DC } & \text { District of Columbia } \\ \text { DOD } & \text { US Department of Defense } \\ \text { DOE } & \text { US Department of Energy } \\ \text { DPCA } & \text { Directorate of Personnel and Community Affairs } \\ \text { DPTMSEC } & \text { Directorate of Plans, Training, Mobilization and Security } \\ \text { DPW } & \text { Directorate of Public Works } \\ \text { DRM } & \text { Directorate of Resource Management } \\ \text { EO } & \text { Executive Order } \\ \text { ERDC } & \text { Engineer Research and Development Center } \\ \text { FY } & \text { fiscal year } \\ \text { HQ } & \text { Headquarters } \\ \text { IMCOM } & \text { Installation Management Command } \\ \text { IT } & \text { Information Technology } \\ \text { ITL } & \text { Information Technology Laboratory } \\ \text { MCA } & \text { Military Construction, Army } \\ \text { OACSIM } & \text { Assistance Chief of Staff for Installation Management } \\ \text { O\&M } & \text { operations and maintenance } \\ \text { R\&D } & \text { research and development } \\ \text { TD } & \text { Technical Director } \\ \text { TR } & \text { US Army Corps of Engineers } \\ \text { USACE } & \end{array}$




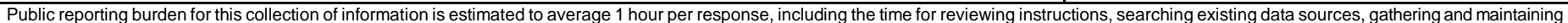

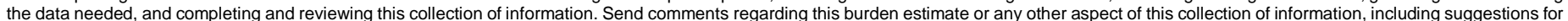



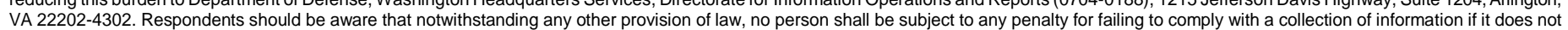
VA 22202-4302. Respondents should be aware that notwithstanding any other provision of law, no person shall be subject
display a currently valid OMB control number. PLEASE DO NOT RETURN YOUR FORM TO THE ABOVE ADDRESS.

\begin{tabular}{l|l} 
1. REPORT DATE (DD-MM-YYYY) & 2. REPORT TYPE
\end{tabular}

July 2012

Final

\section{TITLE AND SUBTITLE}

Emerging Challenges and Opportunities in Building Information Modeling for the

US Army Installation Management Command

3. DATES COVERED (From - To)

5a. CONTRACT NUMBER

5b. GRANT NUMBER

5c. PROGRAM ELEMENT NUMBER

6. AUTHOR(S)

Beth A. Brucker, E. William East, Lance R. Marrano, Michael P. Case, William D.

Goran, Allan Carroll, and Gus DeJesus

5d. PROJECT NUMBER

5e. TASK NUMBER

5f. WORK UNIT NUMBER

7. PERFORMING ORGANIZATION NAME(S) AND ADDRESS(ES)

US Army Engineer Research and Development Center

Construction Engineering Research Laboratory

8. PERFORMING ORGANIZATION REPORT

NUMBER

P.O. Box 9005

Champaign, IL 61826-9005

ERDC/CERL SR-12-8

\section{SPONSORING I MONITORING AGENCY NAME(S) AND ADDRESS(ES)}

US Army Installation Management Command

2511 Jefferson Davis Hwy.

Arlington, VA 22202

10. SPONSOR/MONITOR'S ACRONYM(S)

IMCOM

11. SPONSOR/MONITOR'S REPORT NUMBER(S)

\section{DISTRIBUTION / AVAILABILITY STATEMENT}

Approved for public release; distribution is unlimited.

\section{SUPPLEMENTARY NOTES}

\section{ABSTRACT}

Building Information Modeling (BIM) is the process of generating and managing building data during a facility's entire life cycle. New BIM standards for computable building information could serve as the foundation for automation and transformation of many current activities of the US Army Installation Management Command (IMCOM). As with any important emerging technology, a key issue for IMCOM is to decide when it makes economic sense to adopt BIM at the enterprise level. Facilities typically have an expected service life of 50-75 years, so the availability of up-to-date facility data through BIM on a moment's notice represents a great potential benefit to building operators and maintainers. This in turn implies that facility owners and occupants will ultimately have the most to gain from enterprise-wide BIM adoption. The purpose of this report is to help IMCOM to better understand the implications of large-scale adoption of BIM in terms of timing, costs, and benefits.

\section{SUBJECT TERMS}

Building Information Modeling (BIM), technology, military installations, management, facility life cycle, construction, sustainability, data interoperability, standards

\section{SECURITY CLASSIFICATION OF:}

\section{a. REPORT}

Unclassified

\section{b. ABSTRACT}

Unclassified

\section{c. THIS PAGE}

Unclassified
17. LIMITATION OF ABSTRACT

\section{NUMBER OF PAGES}

42 19a. NAME OF RESPONSIBLE PERSON

19b. TELEPHONE NUMBER (include area code) 